\title{
Endocrine Disruptors and Gut Microbiome Interactions
}

\author{
Richard HAMPL ${ }^{1}$, Luboslav STÁRKA ${ }^{1}$ \\ ${ }^{1}$ Institute of Endocrinology, Prague, Czech Republic
}

Received March 4, 2020

Accepted March 19, 2020

\begin{abstract}
Summary
Anthropogenic environmental pollutants affect many physiological, biochemical, and endocrine actions as reproduction, metabolism, immunity, behavior and as such can interfere with any aspect of hormone action. Microbiota and their genes, microbiome, a large body of microorganisms, first of all bacteria and co-existing in the host's gut, are now believed to be autonomous endocrine organ, participating at overall endocrine, neuroendocrine and immunoendocrine regulations. While an extensive literature is available on the physiological and pathological aspects of both players, information about their mutual relationships is scarce. In the review we attempted to show various examples where both, endocrine disruptors and microbiota are meeting and can act cooperatively or in opposition and to show the mechanism, if known, staying behind these actions.
\end{abstract}

\section{Key words}

Endocrine disruptors • Gut microbiome - Reproduction • Metabolism • Immunity • Mental health

\section{Corresponding author}

R. Hampl, Institute of Endocrinology, Národní 8, 11694 Prague 1, Czech Republic. E-mail: rhampl@endo.cz

\section{Introduction}

Environmental factors known as endocrine disruptors affect many physiological, biochemical, and endocrine actions as reproduction, metabolism, immunity, behavior and as such can interfere with any aspect of hormonal action. For reviews see the particular chapters below. Several reports addressing this issue were reported also in this journal (Müllerová and Kopecký 2007, Vitku et al. 2015, Kolatorova et al. 2017, Kolatorova et al. 2018a, Kolatorova et al. 2018b, Vitku et al. 2018, Jambor et al. 2019).

Gut microbiota participates at many of these processes and is often considered as a further autonomous endocrine organ. Gut microbiota, first of all bacteria, produce a number of biologically active molecules which via signaling pathways, influence physiological functions, while in turn, the host affects considerably microbiome composition and activities. Through permeable gut wall endocrine disruptors from circulation enter directly the intestinal milieu or, by interaction with enteric nervous system, may affect composition and functions of gut microbiome. Out of thousands reports and reviews let us mention at least Cresci and Bawden 2015, Heintz-Buschart and Wilmes 2018, Salvucci 2019.

Gut dysbiosis, as a state consisting of prevalence of non-commensal bacteria might in turn result in many disorders such as obesity, diabetes, gastrointestinal, endocrine, immunological, and neurobehavioral diseases (Rosenfeld 2017). Such host diseases can originate due to shifts in microbiota composition favoring more pathogenic species and phyla.

Both gut microbiota and endocrine disruptors may affect the same physiological and pathological processes mentioned above, though often in a different way. Table 1 shows the number of references collected on PubMed to the date $30^{\text {th }}$ September 2019, concerning the effects of gut microbiota at one side, and endocrine disruptors at another, on reproduction, immunity, diabetes plus related disorders, and mental diseases. The key words in the table were used for the search.

In this overview we attempted to show the main ways how various endocrine disruptors influence gut microbiome richness and composition with consequent pathological outcomes. 
Table 1. Number of papers addressing the effect of endocrine disruptors on microbiome composition and vice versa and papers dealing with relation(ship) of gut microbiota to reproduction, diabetes and related disorders, immunity and mental/or brain disorders (left column) and analogically their relation to endocrine disruptors (right column).

\begin{tabular}{lcc}
\hline $\begin{array}{l}\text { Gut } \\
\text { microbiota }\end{array}$ & $\mathbf{1 4}$ & $\begin{array}{c}\text { Endocrine } \\
\text { disruptors }\end{array}$ \\
\hline 655 & Reproduction & 3655 \\
4575 & Immunity & 289 \\
1501 & Diabetes, obesity, & 307 \\
218 & metabolic syndrome & 711 \\
\hline
\end{tabular}

\section{Studies on the effect of endocrine disruptors on the composition and function of microbiota}

From the data of Table 1 it is evident that there are only few reports concerning the effect of endocrine disruptors on host microbiome. Several reviews have been published recently: Velmurugan et al. 2017, Rosenfeld 2017, Feng et al. 2018, Evariste et al. 2019.

The first review from Indian authors (Velmurugan et al. 2017) focused on the role of gut microbiota in glucose dysregulation induced by individual classes of endocrine disruptors (EDs) from plastics, pesticides, synthetic fertilizers, electronic waste, and food additives. They included bisphenols, dioxins, phthalates, organochlorines, organophosphates, fungicides, polychlorinated biphenyls and polychlorinated dibenzofurans. They have shown increasing incidence of diabetes characterized by hyperglycemia, glucose intolerance and insulin resistance, hand in hand with amount of produced EDs-containing waste pollutants, many of which act as diabetogenes. The increase of diabetes prevalence, at least in India, did not correlate with common risk diabetic factors - obesity, hypertension, hypercholesterolemia or smoking, emphasizing the role of the latter chemicals. At the same time hyperglycemia was associated with changes of microbiota composition, preferring the non-commensal ones, on the detriment of beneficial phyla such as Bacilli (e.g. Lactobacillus), Bacteroidetes, Proteobacteria, and Actinobacteria. The ratio Bacteroidetes/Firmicutes correlated with plasma glucose concentration. Microbiota are capable to ferment undigested carbohydrates, fiber, and other dietary and xenobiotic compounds to produce short-chain fatty acids (SCFAs), which, through their ubiquitous receptors, play an important role in host glucose metabolism. EDs interfere with the latter gut microbial processes, consisting in induction of specific microbial genes, enzymes, and metabolites. Microbiota, in turn may transform EDs into new compounds which may differ in their biological activity. A typical example is DDT, which is dechlorinated by gut microbiota to DDD.

The mutual relationship between environmental exposure to EDs, host status, especially as concerns the pathophysiological situations mentioned in Table 1, and gut microbiome changes was comprehensively reviewed by Rosenfeld (2017). The author collected original papers published until 2017, all of which dealt with animal models. In summary, EDs change hormonal function either by affection of hormonal biosynthesis or by interaction with hormonal receptors. EDs affect production of various steroid and peptide hormones as estrogens, testosterone, glucocorticoids, insulin and likely other hormones. Altered hormonal milieu may result in changes of gut microbiota and dysbiosis. EDs can impact gut microbiota also directly, especially during the perinatal period, when microbes begin to colonize the gut. It is likely that certain bacteria are differently vulnerable to environmental chemical exposures. An example is the effect of bisphenol A (BPA) the exposure to which led to microbiota changes similar to those elicited by high fat diet. Generally, dysbiosis is characterized by altered production of signal molecules by microbiota as already mentioned SCFA, neurotransmitters, cytokines and last but not least hormones, some of which are further metabolized (example: $\beta$-glucuronidase).

The review of Chinese authors (Feng et al. 2018) collected the recent data on the impact of selected environmental contaminants as heavy metals, antibiotics and pesticides on gut microbiome composition and its influence on host physiology. It included organophosphate insecticides chloropyrifos, malathion, diazinon and glyphosate, organochlorine pesticides as permethrin and pentachlorophenol, all acting as EDs. They brought evidence that several commensal bacteria as Lactobacilli can diminish the accumulation and toxicity of pesticides in animal tissues by inhibiting intestinal absorption of contaminants and promoting tight junctions which constitute the intestinal barrier. Microbiota is also capable to transform several EDs to metabolites differing in their toxic properties as demonstrated on organophosphate insecticide chloropyrifos. The second part is focused on the effects of probiotics on improving 
the microbiome composition, following exposure to above mentioned environmental agents. In summary, probiotics as e.g. Lactobacilli protect against EDs induced oxidative stress and consequent cellular damage, contribute to integrity of intestinal barrier, resulting in EDs absorption and stimulate host's immunity.

Recent review from France (Evariste et al. 2019) focused on aquatic organisms. It shows how various environmental contaminants contribute to modifications of gut bacterial communities and dysbiosis. All the cited studies of the microbiota changes were based on 16S rRNA sequencing. Besides heavy metals, antibiotics, nanoparticles and personal health products it included a pesticide pentachlorophenol, a fungicide imazalil (enilconazol), a herbicide atrazine, an antimicrobial agent triclosan, groups of polychlorinated biphenyls and polybrominated diphenyl ethers and BPA. In most but not all instances exposure to the pollutants led to an increase of non-commensal microbiota, on the detriment of beneficial bacterial phyla as characterized e.g. by the Firmicutes/Bacteroidetes ratio. From this point of view, rather surprising is the effect BPA, which at least in zebra fish decreased proportion of Bacteroidetes and increased proportion of phylum CKC4. The review also summarizes the literature on abilities of microbiota to biotransformation of individual classes of environmental pollutants and thus to modulate their toxicity.

Table 2 summarizes the recent studies on environmental chemical pollutants and their coincident effects on host physiology and gut microbiota/ microbiome changes. Most of them act also as classical endocrine disruptors, though the cited papers can deal with other impacts on host physiology. As may be seen, most original papers dealt with bisphenol A, first of all thanks to its effects as an environmental estrogen, but impact of its exposure is not limited only to reproduction. Some of these papers are mentioned in the above cited reviews (Velmurugan et al. 2017, Rosenfeld 2017, Feng et al. 2018, Evariste et al. 2019).

On the other hand there are many examples where the effects of EDs and gut microbiota are meeting, as we attempt to show in the following text.

\section{Endocrine disruptors, gut microbiota, and reproduction}

EDs affect male as well as female reproduction. The last decades monitor the decrease of sperm count and quality in men as well as in wild life, which are related to exposure to various anthropogenic pollutants (Mauduit et al. 2006, Di Nisio and Foresta 2019). EDs represent the risk for female health and reproduction as well, including harmful transgeneration effects on offsprings (Waring and Harris 2011). Extensive literature is available on this topic (Table 1) including a number of reviews and metaanalyses (Gore et al. 2015, Kabir et al. 2015, Sifakis et al. 2017). In summary, EDs in males influence spermatogenesis and semen quality, in females conception, pregnancy and delivery. La Merrill et al. (2020) defined the main levels (named as key factors), where EDs interfere with hormone action, resulting in reproduction disorders: EDs can interact with hormone receptor either as activator or antagonist and even can alter hormone receptor expression. EDs can alter hormone elicited signal transduction, including changes in protein or RNA expression and post-translational modifications in hormone-responsive cells. EDs can induce epigenetic modifications in hormone-producing or hormone-responsive cells. EDs can alter hormone synthesis and thus change hormone distribution or circulating hormone level. This concerns especially hormonal steroids. EDs can alter hormone transport across cell membranes by affecting their permeability. EDs are able to affect hormone metabolism or clearance, resulting in further changes of their circulating levels. Below are shown typical examples where EDs and gut microbiota may act in common either as agonist or antagonist.

The main effect of EDs on male reproduction disorders, such as impaired spermatogenesis and abnormal sperm production, consists in disruption of testicular steroidogenesis in Leydig cells (Vitku et al. 2016, Jambor et al. 2019). Wan et al. (2013) described the sites of hormonal events leading to androgen production, at which EDs can execute their effects. Both expression of key players in hormone signaling and inhibition of mitochondrial enzymes of androgen biosynthesis may occur. Certain fecal microbiota are capable not only to metabolize, but also to synthesize steroid hormones. The historical view on enzymology of steroid transformations carried out by microbiota can be found in the paper of Devendran et al. (2018). So far only little information is available on association between EDs-caused impaired steroidogenesis and gut microbiota (Ding et al. 2020). This issue, especially the possible beneficial counteracting effect of commensal bacteria on concrete EDs-induced errors in androgen production, need further investigation. 


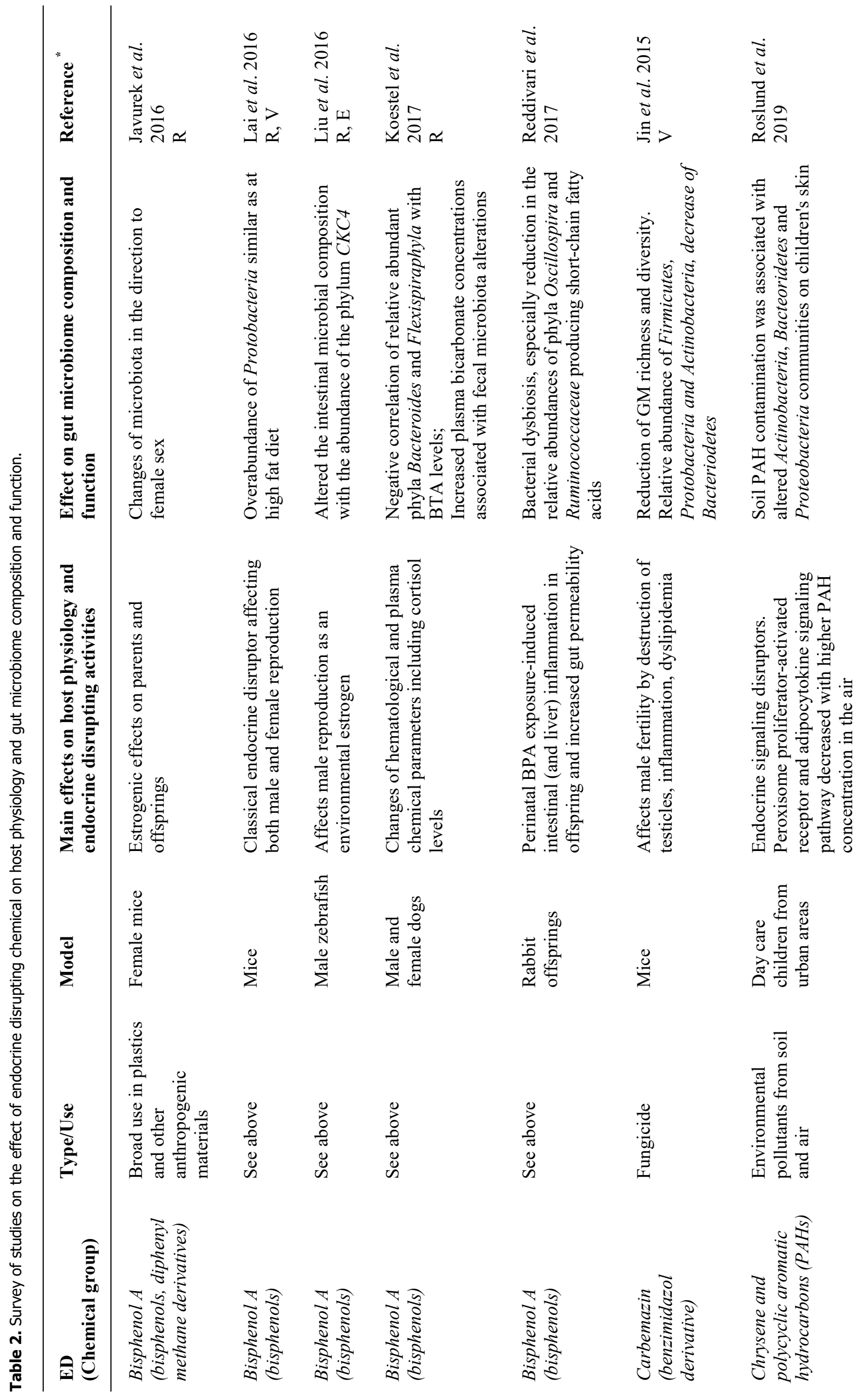




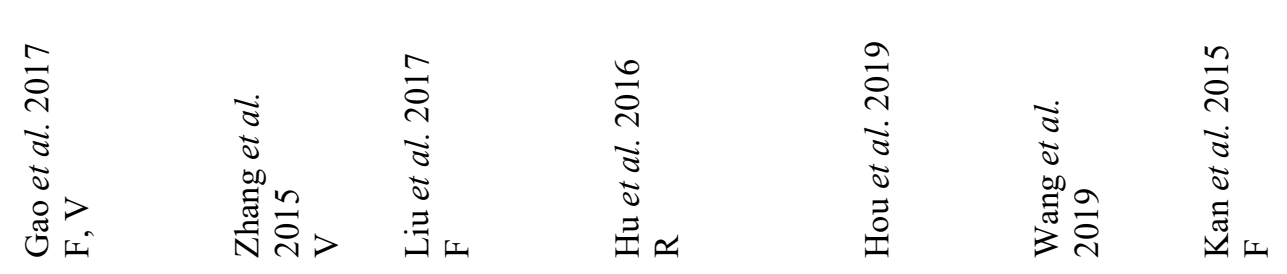

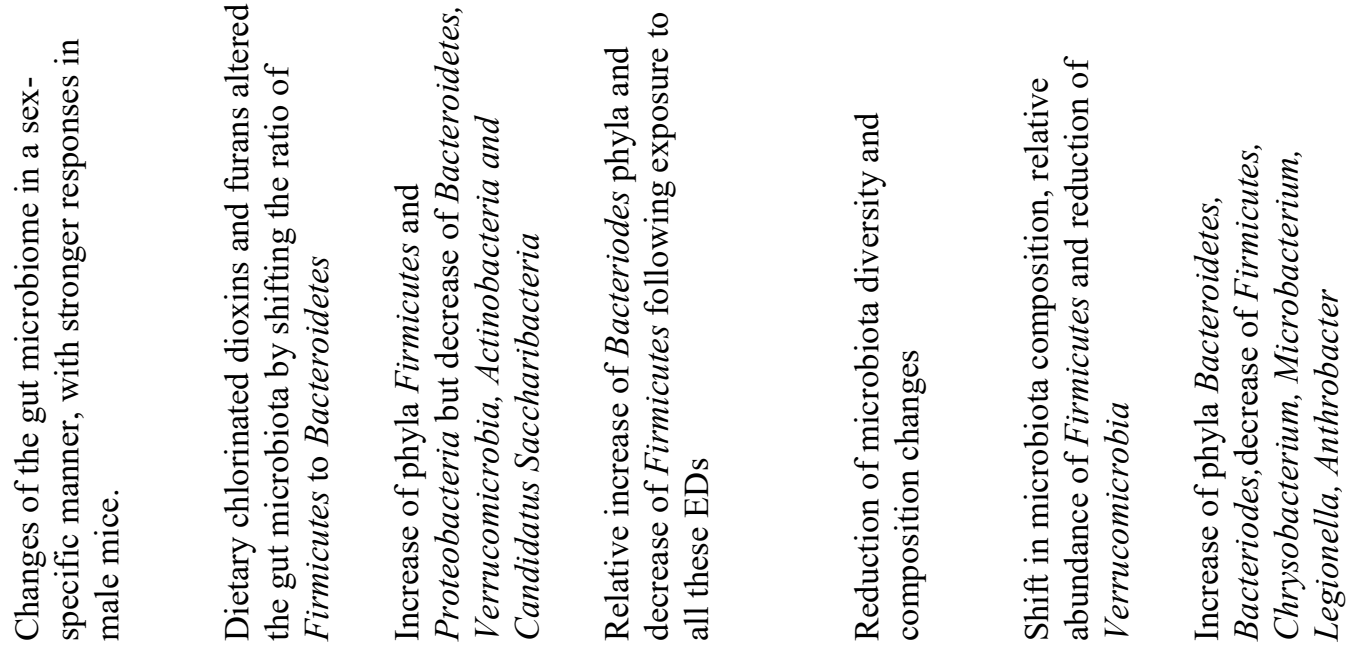

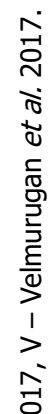

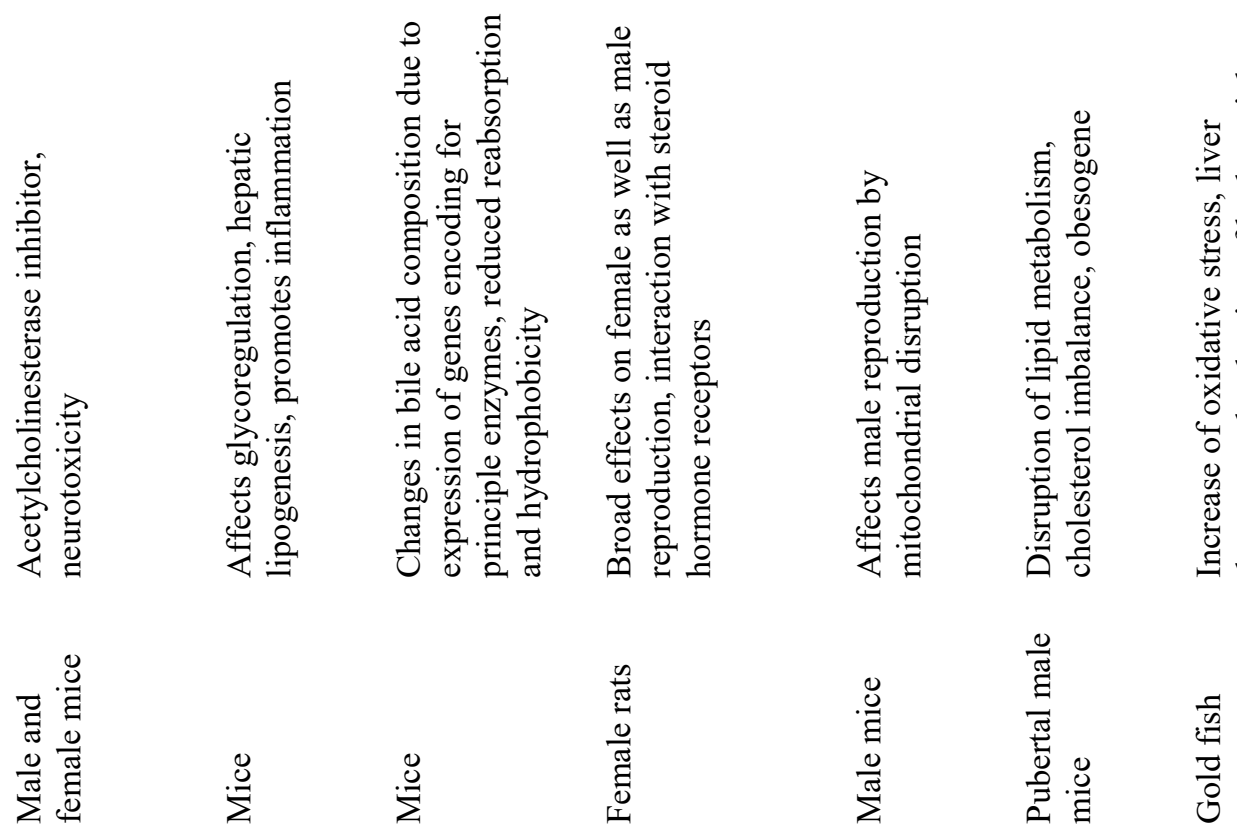

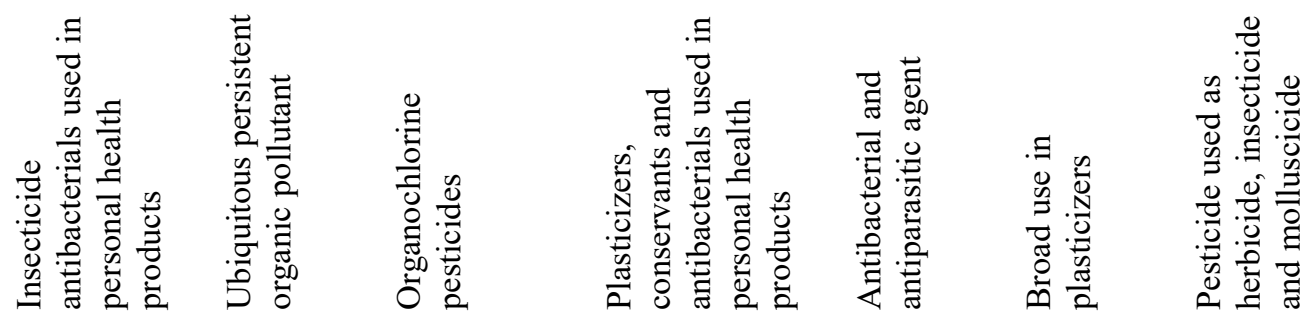

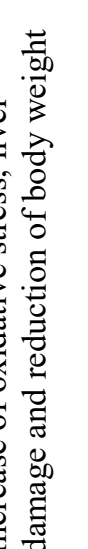


As demonstrated in mice, several EDs such as bisphenols compromise blood-testis barrier integrity and consequently sperm quantity and quality ( $\mathrm{Wu}$ et al. 2019). Gut microbiota are necessary for proper formation of the blood-testis barrier (BTB), as demonstrated by increased BTB permeability in germ free mice. In these animals expression of proteins forming tight junctions of BTB (occludin, ZO-2 and E-cadherin) is reduced. Exposure of these animals to certain commensal bacteria as e.g. Clostridium Tyrobutyricum, which secretes short chain fatty acids, restored BTB integrity. Gut microbiota thus protects germ cells from environmental noxious substances including endocrine disruptors (Al-Asmakh et al. 2014).

As many as 450 compounds including the main classes of EDs possess estrogenic activity and as such affect reproductive functions in both females and males (Kiyama and Wada-Kiyama 2015). One of the key steroid metabolizing enzyme is $\beta$-glucuronidase. Gut microbial $\beta$-glucuronidase enzymes are a part of the the estrobolome, the collection of microbial reactions involving estrogens, which reactivate estrogens and regulate their circulating levels (Ervin et al. 2019). Recent experiments gave evidence that some estrogenic EDs may undergo glucuronisation (Andra et al. 2016). It can be expected that gut microbiota would participate in this reaction.

Polycystic ovary syndrome (PCOS), one of the most common female reproductive disorder, is characterized among other by steroid hormone dysregulation resulting in hyperandrogenemia. Recent studies have shown that it is often associated with gut microbiota dysbiosis, characterized by decreased bacteria diversity and changes in specific Bacteroidetes and Firmicute phyla (Thackray 2019). Using letrozoleinduced PCOS mouse model, the causative role of gut microbiome dysbiosis in PCOS was proven (Torres et al. 2019). Association between PCOS and exposure to various endocrine disruptors has been repeatedly described and reviewed (Hu et al. 2018, Barrett and Sobolewski 2014, Palioura and Diamanti-Kandarakis 2015). It concerns first of all those compounds with (anti)estrogenic activity as bisphenol A (Hu et al. 2018). BPA concentrations in serum are higher in women with PCOS than in healthy women, but the causality, in contrast to animals, has not been established. Further work is needed to understand the mechanisms by which EDs contribute to PCOS and how changes in microbiota composition can contribute to counteract the effects of EDs.

\section{Endocrine disruptors, gut microbiota, diabetes, obesity and related disorders}

Many endocrine disruptors act as obesogens and are involved in exacerbation or even are responsible for diabetes of both types (for number of papers see Table 1). It concerns all main classes of EDs as bisphenols, phthalates, polychlorinated biphenyls, organochlorine pesticides, dioxins and parabens (Ruiz et al. 2018). As such, EDs increase adipogenesis by promoting the responsive genes, affect the mechanisms of hormone regulation of food intake, appetite and satiety, influence rest fuel metabolism, may cause disruption of pancreatic $\beta$-cell function an worsen insulin sensitivity; only typical reviews are cited here (Chevalier and Fénichel 2015, Casals-Casas and Desvergne 2011, Bodin et al. 2015, Petrakis et al. 2017).

Hundreds of recent reviews addressed also the issue of the role of gut microbiota in obesity, diabetes and related disorders including the metabolic syndrome, as e.g. Barlow et al. 2015, Maruvada et al. 2017, Bouter et al. 2017, Chen and Devaraj 2018, Vallianou et al. 2018. Generally, almost all the above disorders are associated with changes of gut microbiota in sense of reduction of commensal bacteria and dysbiosis. However, in the next paragraph(s) let us show a few concrete situations where EDs and gut microbiota act in parallel or are meeting:

Bisphenol A and many other EDs affect insulin synthesis and/or release by pancreatic $\beta$-cells and insulin signaling within insulin-sensitive organs including gut, which may lead to insulin resistance (Le MagueresseBattistoni et al. 2018). Opening of the calcium channel and influx of $\mathrm{Ca}^{2+}$ ions into the cells is the last step of signaling cascade in the regulation of insulin release (by exocytosis) from $\beta$-cells after uptake of glucose. Bisphenol A can interact with $\mathrm{Ca}^{2+}$ channel resulting in insulin resistance (Ahn et al. 2018). A causal link between the intestinal microbiota dysbiosis and insulin resistance was confirmed in both rodents and humans (Saad et al. 2016). The latter authors summed up the mechanisms through which microbiota may act. It would be of interest to look for other common points linking the effect of EDs and microbiota.

One of the effects of microbiota is its influencing gastrointestinal mucosa permeability (compare the effect on blood-testis barrier). By fermentation of dietary polysaccharides they produce short-chain fatty acids, which, through their membrane 
receptors in intestinal mucosa, may alter tight junctions between the cells (Blandino 2016). Exposure to some EDs, namely polychlorinated biphenyls also resulted in disruption of gut permeability via decreased expression of tight junctions proteins (Choi et al. 2010).

The fungicide tributyltin (an organometallic compound with tin) is a potent obesogen which induces adipogenesis by interacting with nuclear PPAR $\gamma$ and its heteromeric partner retinoid X receptor. Recent report showed that at least in mice tributyltin treatment decreased gut microbial species and changed the microbiome composition (Guo et al. 2018).

\section{Endocrine disruptors, gut microbiota and immunity}

There are many examples how EDs affect both innate as well as acquired immunity as evident from Table 1; for recent review see e.g. Bansal et al. 2018. EDs affect the development, differentiation and functions of various immune cells, lymphocytes, monocytes, dendritic cells, neutrophils, mast cells, eosinophils and natural killers (Nowak et al. 2019). The commensal gut microbiota regulates the maturation of the mucosal immune system, while the pathogenic microbiome causes immunity dysfunction, resulting in disease development. The gut mucosal immune system constitutes a protective barrier for the integrity of the intestinal tract. Endocrine disruptors and other toxicants may impair the function of mucosal intestine barrier (Coruzzi 2010, Feng et al. 2018), similarly as do pathogenic microbiota (Takiishi et al. 2017).

EDs may cause or exacerbate immunity-related diseases as diabetes, asthma, allergy and endocrine autoimmune diseases (Nowak et al. 2018). The parallel action of endocrine disruptors and gut microbiota on development of diabetes and insulin resistance was discussed in the previous chapter.

Endocrine disruptors are believed to contribute to development of autoimmune endocrinopathies, including the most frequent ones, autoimmune thyroid diseases (AITD), as evidenced indirectly by higher prevalence of AITD in polluted areas (Benvega et al. 2020). Among EDs the prominent one is BPA due to its immune stimulatory activity (Aljadeff et al. 2018). Gut microbiota via its surface signaling molecules and metabolic products can communicate with cells of innate immune system. Under dysbiosis this communication is disturbed and thus might contribute to development of autoimmunity (Thaiss et al. 2016). Generally, gut microbiota dysbiosis has been repeatedly observed in many autoimmune diseases as intestinal autoimmune diseases, type 1 diabetes mellitus, systemic sclerosis, systemic lupus erythematosus and last but not least in autoimmune thyroid disease (AITD), first of all in the most frequent autoimmune disorder worldwide, Hashimoto's thyroiditis (Virili et al. 2018).

Another widespread group of autoimmune disorders of Western population is inflammatory bowel disease. Hundreds of original papers, metaanalyses and reviews gave evidence for its relation to composition and structure of gut microbiota (Sartor and Wu 2017, Nishida et al. 2018), while only a few pointed so far to involvement of EDs, suggesting the way for further research (de Silva et al. 2017).

\section{Endocrine disruptors, gut microbiota and mental disorders}

As apparent from Table 1, endocrine disruptors can influence the brain development and actions. A crucial role for optimal brain function during prenatal period as well as during maturity and even senescence play gonadal hormones, in concert with thyroid hormones. They are indispensable in the processes of neurogenesis, they protect against neurodegenerative disorders and support cognitive activities. The impact of EDs consists in affecting hormonal mechanism of action by interacting with the respective receptors and signaling, and influencing hormone biosynthesis (Sanderson 2006). In addition EDs may act directly by modulation of neuronal transmission (Weiss 2011, Schug et al. 2015). As such, EDs are involved in onset and development of most severe neurodegenerative diseases (Alzheimer's and other dementias, Parkinsonism, multiple sclerosis). As shown in previous paragraphs, EDs contribute to impairment of insulin signaling and sensitivity, one of characteristic features (signs) of Alzheimer's dementia (Wang et al. 2017). More recent reports point also to their harmful neurobehavioral effects including autistic spectrum disorders (Tareen and Kamboj 2012).

Gut microbiota is capable to synthesize and metabolize steroid hormones and as such contribute to their circulating levels and indirectly affect the brain development and function (Vom Steeg and Klein 2017). Less information is available as concerns the role of microbiota in thyroid hormone biosynthesis and metabolism (Virili and Centanni 2017). Many reports 
provide evidence for association of neurodegenerativeand even neuropsychiatric diseases with gut microbiota dysbiosis (Jiang et al. 2017, Colpitts and Kasper 2017, Dopkins et al. 2018, Stefano et al. 2018). As mentioned already, endocrine disruptors belong to environmental factors causing gut microbiota dysbiosis (Velmurugan et al. 2017, Rosenfeld 2017), indicating a link between both players. While the effects of EDs on biochemical and molecular levels are in most instances known, the causal relationship between the effects of microbiota is not clear so far; it would be interesting to look for mechanisms responsible for these effects.

Besides gonadal steroids let us mention the glucocorticoids and their role in neuroendocrine signaling in the axis microbiota-gut-brain. An important peripheral enzyme regulating actual concentration of glucocorticoids is $11 \beta$-hydroxysteroid dehydrogenase type 1 , which is the target of various EDs and belongs also to enzymatic arsenal of gut microbiome (Ohshima et al. 2017, Johnson et al. 2017).

\section{Conclusion}

Environmental pollutants known as endocrine disruptors affect various physiological functions and are responsible for some harmful effects, manifesting themselves as various diseases or their exacerbation. Large body of literature is available about their effect on reproduction, immunity, development of diabetes and related disorders and even on mental health. Gut microbiome, a composition of bacteria and other microorganisms, co-existing in the gut with the host, is now believed to function as an autonomous endocrine organ, participating in endocrine and neuroendocrine regulations. The dysbiosis, a state consisting in an imbalance between commensal, beneficial bacteria and pathogens, often results in a disease.

Generally EDs can cause dysbiosis. While there is a lot of reports, reviews and metaanalyses dealing with the effects of EDs on one side, and analogically on the role of microbiome and its association with various physiological or pathological states on another, the literature on the mutual relationships between EDs and gut microbiome is relatively scarce.

The aim of this review is not only to show the ways and examples how EDs influence the function of gut microbiome, but first of all to point to connecting links where both players are meeting, i.e. act in parallel or against one another, even though the mechanisms staying behind may differ. We believe that it could suggest the way for further research.

\section{Conflict of Interest}

There is no conflict of interest.

\section{Acknowledgements}

The work was supported by the project of the Czech Ministry of the Health - RVO Institute of Endocrinology, EU 00023761.

\section{References}

AHN C, KANG HS, LEE JH, HONG EJ, JUNG EM, YOO YM, JEUNG EB: Bisphenol A and octylphenol exacerbate type 1 diabetes mellitus by disrupting calcium homeostasis in mouse pancreas. Toxicol Lett 295: 162-172, 2018. https://doi.org/10.1016/j.toxlet.2018.06.1071

AL-ASMAKH M, STUKENBORG JB, REDA A, ANUAR F, STRAND ML, HEDIN L, PETTERSSON S, SÖDER O: The gut microbiota and developmental programming of the testis in mice. PLoS One 9: e103809, 2014. https://doi.org/10.1371/journal.pone.0103809

ALJADEFF G, LONGHI E, SHOENFELD Y: Bisphenol A: a notorious player in the mosaic of autoimmunity. Autoimmunity 51: 370-377, 2018. https://doi.org/10.1080/08916934.2018.1551374

ANDRA SS, AUSTIN C, YANG J, PATEL D, ARORA M: Recent advances in simultaneous analysis of bisphenol A and its conjugates in human matrices: exposure biomarker perspectives. Sci Total Environ 572: 770-781, 2016. https://doi.org/10.1016/j.scitotenv.2016.07.062

BANSAL A, HENAO-MEJIA J, SIMMONS RA: Immune system: an emerging player in mediating effects of endocrine disruptors on metabolic health. Endocrinology 159: 32-45, 2018. https://doi.org/10.1210/en.2017$\underline{00882}$

BARLOW GM, YU A, MATHUR R: Role of the gut microbiome in obesity and diabetes mellitus. Nutr Clin Pract 30 : 787-797, 2015. https://doi.org/10.1177/0884533615609896 
BARRETT ES, SOBOLEWSKI M: Polycystic ovary syndrome: do endocrine-disrupting chemicals play a role? Semin Reprod Med 32: 166-176, 2014. https://doi.org/10.1055/s-0034-1371088

BENVENGA S, ELIA G, RAGUSA F, PAPARO SR, STURNIOLO MM, FERRARI SM, ANTONELLI A, FALLAHI P: Endocrine disruptors and thyroid autoimmunity. Best Pract Res Clin Endocrinol Metab 11: 101377, 2020. https://doi.org/10.1016/j.beem.2020.101377

BLANDINO G, INTURRI R, LAZZARA F, DI ROSA M, MALAGUARNERA L: Impact of gut microbiota on diabetes mellitus. Diabetes Metab 42: 303-315, 2016. https://doi.org/10.1016/j.diabet.2016.04.004

BODIN J, STENE LC, NYGAARD UC: Can exposure to environmental chemicals increase the risk of diabetes type 1 development? Biomed Res Int 2015: 208947, 2015. https://doi.org/10.1155/2015/208947

BOUTER KE, VAN RAALTE DH, GROEN AK, NIEUWDORP M: Role of the gut microbiome in the pathogenesis of obesity and obesity-related metabolic dysfunction. Gastroenterology 152: 1671-1678, 2017. https://doi.org/10.1053/j.gastro.2016.12.048

CASALS-CASAS C, DESVERGNE B: Endocrine disruptors: from endocrine to metabolic disruption. Annu Rev Physiol 73: 135-162, 2011. https://doi.org/10.1146/annurev-physiol-012110-142200

CHEN X, DEVARAJ S: Gut microbiome in obesity, metabolic syndrome, and diabetes. Curr Diab Rep 18: 129, 2018. https://doi.org/10.1007/s11892-018-1104-3

CHEVALIER N, FÉNICHEL P: Endocrine disruptors: new players in the pathophysiology of type 2 diabetes? Diabetes Metab 41: 107-115, 2015. https://doi.org/10.1016/j.diabet.2014.09.005

CHOI YJ, SEELBACH MJ, PU H, EUM SY, CHEN L, ZHANG B, HENNIG B, TOBOREK M: Polychlorinated biphenyls disrupt intestinal integrity via NADPH oxidase-induced alterations of tight junction protein expression. Environ Health Perspect 118: 976-981, 2010. https://doi.org/10.1289/ehp.0901751

COLPITTS SL, KASPER LH: Influence of the gut microbiome on autoimmunity in the central nervous system. J Immunol 198: 596-604, 2017. https://doi.org/10.4049/jimmunol.1601438

CORUZZI G: Overview of gastrointestinal toxicology. Curr Protoc Toxicol Chapter 21: Unit 21.1, 2010. https://doi.org/10.1002/0471140856.tx2101s43

CRESCI GA, BAWDEN E: Gut microbiome: what we do and don't know. Nutr Clin Pract 30: 734-746, 2015. https://doi.org/10.1177/08845333615609899

DE SILVA PS, YANG X, KORZENIK JR, GOLDMAN RH, ARHEART KL, CABAN-MARTINEZ AJ: Association of urinary phenolic compounds, inflammatory bowel disease and chronic diarrheal symptoms: evidence from the National Health and Nutrition Examination Survey. Environ Pollut 229: 621-626, 2017. https://doi.org/10.1016/j.envpol.2017.06.023

DEVENDRAN S, MYTHEN SM, RIDLON JM: The desA and desB genes from Clostridium scindens ATCC 35704 encode steroid-17,20-desmolase. J Lipid Res 59: 1005-1014, 2018. https://doi.org/10.1194/jlr.M083949

DING N, ZHANG X, ZHANG XD, JING J, LIU SS, MU YP, PENG LL, YAN YJ, XIAO GM, BI XY, CHEN H, LI FH, YAO B, ZHAO AZ: Impairment of spermatogenesis and sperm motility by the high-fat diet-induced dysbiosis of gut microbes. Gut 0: gutjnl-2019-319127, 2020. https://doi.org/10.1136/gutjnl-2019-319127

DI NISIO A, FORESTA C: Water and soil pollution as determinant of water and food quality/contamination and its impact on male fertility. Reprod Biol Endocrinol 17: 4, 2019. https://doi.org/10.1186/s12958-018-0449-4

DOPKINS N, NAGARKATTI PS, NAGARKATTI M: The role of gut microbiome and associated metabolome in the regulation of neuroinflammation in multiple sclerosis and its implications in attenuating chronic inflammation in other inflammatory and autoimmune disorders. Immunology 154: 178-185, 2018. https://doi.org/10.1111/imm.12903

ERVIN SM, LI H, LIM L, ROBERTS LR, LIANG X, MANI S, REDINBO MR: Gut microbial $\beta$-glucuronidases reactivate estrogens as components of the estrobolome that reactivate estrogens. J Biol Chem 294: 18586-18599, 2019. https://doi.org/10.1074/jbc.RA119.010950

EVARISTE L, BARRET M, MOTTIER A, MOUCHET F, GAUTHIER L, PINELLI E: Gut microbiota of aquatic organisms: a key endpoint for ecotoxicological studies. Environ Pollut 248: 989-999, 2019. https://doi.org/10.1016/j.envpol.2019.02.101 
FENG P, YE Z, KAKADE A, VIRK AK, LI X, LIU P: A review on gut remediation of selected environmental contaminants: possible roles of probiotics and gut microbiota. Nutrients 11: E22, 2018. https://doi.org/10.3390/nu11010022

GAO B, BIAN X, MAHBUB R, LU K: Sex-specific effects of organophosphate diazinon on the gut microbiome and its metabolic functions. Environ Health Persp 125: 198-206, 2017. https://doi.org/10.1289/EHP202

GORE AC, CHAPPELL VA, FENTON SE, FLAWS JA, NADAL A, PRINS GS, TOPPARI J, ZOELLER RT: EDC-2: The Endocrine Society's second scientific statement on endocrine-disrupting chemicals. Endocr Rev 36: E1-E150, 2015. https://doi.org/10.1210/er.2015-1010

GUO H, YAN H, CHENG D, WEI X, KOU R, SI J: Tributyltin exposure induces gut microbiome dysbiosis with increased body weight gain and dyslipidemia in mice. Environ Toxicol Pharmacol 60: 202-208, 2018. https://doi.org/10.1016/j.etap.2018.04.020

HEINTZ-BUSCHART A, WILMES P: Human gut microbiome: function matters. Trends Microbiol 26: 563-574, 2018. https://doi.org/10.1016/j.tim.2017.11.002

HOU X, ZHU L, ZHANG X, ZHANG L, BAO H, TANG M, WEI R, WANG R: Testosterone disruptor effect and gut microbiome perturbation in mice: early life exposure to doxycycline. Chemosphere 222: 722-731, 2019. https://doi.org/10.1016/i.chemosphere.2019.01.101

HU J, RAIKHEL V, GOPALAKRISHNAN K, FERNANDEZ-HERNANDEZ H, LAMBERTINI L, MANSERVISI F, FALCIONI L, BUA L, BELPOGGI F, L TEITELBAUM S, CHEN J: Effect of postnatal low-dose exposure to environmental chemicals on the gut microbiome in a rodent model. Microbiome 4: 26, 2016. https://doi.org/10.1186/s40168-016-0173-2

JAMBOR T, KOVACIKOVA E, GREIFOVA H, KOVACIK A, LIBOVA L, LUKAC N: Assessment of the effective impact of bisphenols on mitochondrial activity and steroidogenesis in a dose-dependency in mice TM3 Leydig cells. Physiol Res 68: 689-693, 2019. https://doi.org/10.33549/physiolres.934200

JAVUREK AB, SPOLLEN WG, JOHNSON SA, BIVENS NJ, BROMERT KH, GIVAN SA, ROSENFELD CS: Effects of exposure to bisphenol A and ethinyl estradiol on the gut microbiota of parents and their offspring in a rodent model. Gut Microbes 7: 471-485, 2016. https://doi.org/10.1080/19490976.2016.1234657

JIANG C, LI G, HUANG P, LIU Z, ZHAO B: The gut microbiota and Alzheimer's disease. J Alzheimers Dis 58: 1-15, 2017. https://doi.org/10.3233/JAD-161141

JIN Y, ZENG Z, WU Y, ZHANG S, FU Z: Oral exposure of mice to carbendazim induces hepatic lipid metabolism disorder and gutmicrobiota dysbiosis. Toxicol Sci 147: 116-126, 2015. https://doi.org/10.1093/toxsci/kfv115

JOHNSON JS, OPIYO MN, THOMSON M, GHARBI K, SECKL JR, HEGER A, CHAPMAN KE: 11ß-hydroxysteroid dehydrogenase-1 deficiency alters the gut microbiome response to Western diet. J Endocrinol 232: 273-283, 2017. https://doi.org/10.1530/JOE-16-0578

KABIR ER, RAHMAN MS, RAHMAN I: A review on endocrine disruptors and their possible impacts on human health. Environ Toxicol Pharmacol 40: 241-258, 2015. https://doi.org/10.1016/j.etap.2015.06.009

KAN H, ZHAO F, ZHANG X-X, REN H, GAO S: Correlations of gut microbial community shift with hepatic damage and growth inhibition of Carassius auratus induced by pentachlorophenol exposure. Environ Sci Technol 49: 11894-11902, 2015. https://doi.org/10.1021/acs.est.5b02990

KIYAMA R, WADA-KIYAMA Y: Estrogenic endocrine disruptors: molecular mechanisms of action. Environ Int 83: 11-40, 2015. https://doi.org/10.1016/j.envint.2015.05.012

KOESTEL ZL, BACKUS RC, TSURUTA K, SPOLLEN WG, JOHNSON SA, JAVUREK AB, ELLERSIECK MR, WIEDMEYER CE, KANNAN K, XUE J, BIVENS NJ, GIVAN SA, ROSENFELD CS: Bisphenol A (BPA) in the serum of pet dogs following short-term consumption of canned dog food and potential health consequences of exposure to BPA. Sci Total Environ 579: 1804-1814, 2017. https://doi.org/10.1016/j.scitotenv.2016.11.162

KOLATOROVA L, DUSKOVA M, VITKU J, STARKA L: Prenatal exposure to bisphenols and parabens and impacts on human physiology. Physiol Res 66 (Suppl 3): S305-S315, 2017. https://doi.org/10.33549/physiolres.933723

KOLATOROVA L, SRAMKOVA M, VITKU J, VCELAK J, LISCHKOVA O, STARKA L, DUSKOVA M: Parabens and their relation to obesity. Physiol Res 67 (Suppl 3): S465-S472, 2018. https://doi.org/10.33549/physiolres.934004 
KOLATOROVA L, VITKU J, VAVROUS A, HAMPL R, ADAMCOVA K, SIMKOVA M, PARIZEK A, STARKA L, DUSKOVA M: Phthalate metabolites in maternal and cord plasma and their relations to other selected endocrine disruptors and steroids. Physiol Res 67 (Suppl 3): S473-S487, 2018. https://doi.org/10.33549/physiolres.933962

LAI KP, CHUNG YT, LI R, WAN HT, WONG CK: Bisphenol A alters gut microbiome: comparative metagenomics analysis. Environ Pollut 218: 923-930, 2016. https://doi.org/10.1080/19490976.2015.1117737

LA MERRILL MA, VANDENBERG LN, SMITH MT, GOODSON W, BROWNE P, PATISAUL HB, GUYTON KZ, KORTENKAMP A, COGLIANO VJ, WOODRUFF TJ, RIESWIJK L, SONE H, KORACH KS, GORE AC, ZEISE L, ZOELLER RT: Consensus on the key characteristics of endocrine-disrupting chemicals as a basis for hazard identification. Nat Rev Endocrinol 16: 45-57, 2020. https://doi.org/10.1038/s41574-019-0273-8

LE MAGUERESSE-BATTISTONI B, MULTIGNER L, BEAUSOLEIL C, ROUSSELLE C: Effects of bisphenol A on metabolism and evidences of a mode of action mediated through endocrine disruption. Mol Cell Endocrinol 475: 74-91, 2018. https://doi.org/10.1111/tan.13252

LIU Q, SHAO W, ZHANG C, XU C, WANG Q, LIU H, SUN H, JIANG Z, GU A: Organochloride pesticides modulated gut microbiota and influenced bile acid metabolism in mice. Environ Pollut 226: 268-276, 2017. https://doi.org/10.1016/j.envpol.2017.03.068

LIU Y, YAO Y, LI H, QIAO F, WU J, DU ZY, ZHANG M: Influence of endogenous and exogenous estrogenic endocrine on intestinal microbiota in zebrafish. PLoS One 11: e0163895, 2016. https://doi.org/10.1371/journal.pone.0163895

MARUVADA P, LEONE V, KAPLAN LM, CHANG EB: The human microbiome and obesity: moving beyond associations. Cell Host Microbe 22: 589-599, 2017. https://doi.org/10.1016/j.chom.2017.10.005

MAUDUIT C, FLORIN A, AMARA S, BOZEC A, SIDDEEK B, CUNHA S, MEUNIER L, SELVA J, ALBERT M, VIALARD F, BAILLY M, BENAHMED M: Long-term effects of environmental endocrine disruptors on male fertility. Gynecol Obstet Fertil 34: 978-984, 2006. https://doi.org/10.1016/j.gyobfe.2006.08.010

MÜLLEROVÁ D, KOPECKÝ J: White adipose tissue: storage and effector site for environmental pollutants. Physiol Res 56: 375-381, 2007.

NISHIDA A, INOUE R, INATOMI O, BAMBA S, NAITO Y, ANDOH A: Gut microbiota in the pathogenesis of inflammatory bowel disease. Clin J Gastroenterol 11: 1-10, 2018. https://doi.org/10.1007/s12328-017-0813-5

NOWAK K, JABŁOŃSKA E, RATAJCZAK-WRONA W: Immunomodulatory effects of synthetic endocrine disrupting chemicals on the development and functions of human immune cells. Environ Int 125: 350-364, 2019. https://doi.org/10.1016/j.envint.2019.01.078

OHSHIMA M, OHNO S, NAKAJIN S: Inhibitory effects of some possible endocrine-disrupting chemicals on the isozymes of human 11beta-hydroxysteroid dehydrogenase and expression of their mRNA in gonads and adrenal glands. Environ Sci 12: 219-230, 2005.

PALIOURA E, DIAMANTI-KANDARAKIS E: Polycystic ovary syndrome (PCOS) and endocrine disrupting chemicals (EDCs). Rev Endocr Metab Disord 16: 365-371, 2015. https://doi.org/10.1007/s11154-016-9326-7

PETRAKIS D, VASSILOPOULOU L, MAMOULAKIS C, PSYCHARAKIS C, ANIFANTAKI A, SIFAKIS S, DOCEA AO, TSIAOUSSIS J, MAKRIGIANNAKIS A, TSATSAKIS AM: Endocrine disruptors leading to obesity and related diseases. Int $\mathrm{J}$ Environ Res Public Health 14: E1282, 2017. https://doi.org/10.3390/ijerph14101282

REDDIVARI L, VEERAMACHANENI DNR, WALTERS WA, LOZUPONE C, PALMER J, HEWAGE MKK, BHATNAGAR R, AMIR A, KENNETT MJ, KNIGHT R, VANAMALA JKP: Perinatal bisphenol A exposure induces chronic inflammation in rabbit offspring via modulation of gut bacteria and their metabolites. mSystems 2: e00093-17, 2017. https://doi.org/10.1128/mSystems.00093-17

ROSENFELD CS: Gut dysbiosis in animals due to environmental chemical exposures. Front Cell Infect Microbiol 7: 396, 2017. https://doi.org/10.3389/fcimb.2017.00396

ROSLUND MI, RANTALA S, OIKARINEN S, PUHAKKA R, HUI N, PARAJULI A, LAITINEN OH, HYÖTY H, RANTALAINEN AL, SINKKONEN A: Endocrine disruption and commensal bacteria alteration associated with gaseous and soil PAH contamination among daycare children. Environ Int 130: 104894, 2019. https://doi.org/10.1016/j.envint.2019.06.004 
RUIZ D, BECERRA M, JAGAI JS, ARD K, SARGIS RM: Disparities in environmental exposures to endocrinedisrupting chemicals and diabetes risk in vulnerable populations. Diabetes Care 41: 193-205, 2018. https://doi.org/10.2337/dc16-2765

SAAD MJ, SANTOS A, PRADA PO: Linking gut microbiota and inflammation to obesity and insulin resistance. Physiology (Bethesda) 31: 283-293, 2016. https://doi.org/10.1152/physiol.00041.2015

SALVUCCI E: The human-microbiome superorganism and its modulation to restore health. Int J Food Sci Nutr 70 : 781-795, 2019. https://doi.org/10.1080/09637486.2019.1580682

SANDERSON JT: The steroid hormone biosynthesis pathway as a target for endocrine-disrupting chemicals. Toxicol Sci 94: 3-21, 2006. https://doi.org/10.1093/toxsci/kfl051

SCHUG TT, BLAWAS AM, GRAY K, HEINDEL JJ, LAWLER CP: Elucidating the links between endocrine disruptors and neurodevelopment. Endocrinology 156: 1941-1951, 2015. https://doi.org/10.1210/en.2014-1734

SIFAKIS S, ANDROUTSOPOULOS VP, TSATSAKIS AM, SPANDIDOS DA: Human exposure to endocrine disrupting chemicals: effects on the male and female reproductive systems. Environ Toxicol Pharmacol 51: 56-70, 2017. https://doi.org/10.1016/j.etap.2017.02.024

STEFANO GB, PILONIS N, PTACEK R, RABOCH J, VNUKOVA M, KREAM RM: Gut, microbiome, and brain regulatory axis: relevance to neurodegenerative and psychiatric disorders. Cell Mol Neurobiol 38: 1197-1206, 2018. https://doi.org/10.1007/s10571-018-0589-2

TAKIISHI T, FENERO CIM, CÂMARA NOS: Intestinal barrier and gut microbiota: shaping our immune responses throughout life. Tissue Barriers 5: e1373208, 2017. https://doi.org/10.1080/21688370.2017.1373208

TAREEN RS, KAMBOJ MK: Role of endocrine factors in autistic spectrum disorders. Pediatr Clin North Am 59: 75-88, 2012. https://doi.org/10.1016/j.pcl.2011.10.013

THACKRAY VG: Sex, microbes, and polycystic ovary syndrome. Trends Endocrinol Metab 30: 54-65, 2019. https://doi.org/10.1016/j.tem.2018.11.001

THAISS CA, ZMORA N, LEVY M, ELINAV E: The microbiome and innate immunity. Nature 535: 65-74, 2016. https://doi.org/10.1038/nature18847

TORRES PJ, HO BS, ARROYO P, SAU L, CHEN A, KELLEY ST, THACKRAY VG: Exposure to a healthy gut microbiome protects against reproductive and metabolic dysregulation in a PCOS mouse model. Endocrinology 160: 1193-1204, 2019. https://doi.org/10.1210/en.2019-00050

VALLIANOU NG, STRATIGOU T, TSAGARAKIS S: Microbiome and diabetes: where are we now? Diabetes Res Clin Pract 146: 111-118, 2018. https://doi.org/10.1016/j.diabres.2018.10.008

VELMURUGAN G, RAMPRASATH T, GILLES M, SWAMINATHAN K, RAMASAMY S: Gut microbiota, endocrine-disrupting chemicals, and the diabetes epidemic. Trends Endocrinol Metab 28: 612-625, 2017. https://doi.org/10.1016/j.tem.2017.05.001

VIRILI C, CENTANNI M: "With a little help from my friends" - The role of microbiota in thyroid hormone metabolism and enterohepatic recycling. Mol Cell Endocrinol 458: 39-43, 2017. https://doi.org/10.1016/j.mce.2017.01.053

VIRILI C, FALLAHI P, ANTONELLI A, BENVENGA S, CENTANNI M: Gut microbiota and Hashimoto's thyroiditis. Rev Endocr Metab Disord 19: 293-300, 2018. https://doi.org/10.1007/s11154-018-9467-y

VITKU J, SOSVOROVA L, CHLUPACOVA T, HAMPL R, HILL M, SOBOTKA V, HERACEK J, BICIKOVA M, STARKA L: Differences in bisphenol A and estrogen levels in the plasma and seminal plasma of men with different degrees of infertility. Physiol Res 64 (Suppl 2): S303-S311, 2015. https://doi.org/10.33549/physiolres.933090

VITKU J, HERACEK J, SOSVOROVA L, HAMPL R, CHLUPACOVA T, HILL M, SOBOTKA V, BICIKOVA M, STARKA L: Associations of bisphenol A and polychlorinated biphenyls with spermatogenesis and steroidogenesis in two biological fluids from men attending an infertility clinic. Environ Int 89-90: 166-173, 2016. https://doi.org/10.1016/j.envint.2016.01.021

VITKU J, KOLATOROVA L, FRANEKOVA L, BLAHOS J, SIMKOVA M, DUSKOVA M, SKODOVA T, STARKA L: Endocrine disruptors of the bisphenol and paraben families and bone metabolism. Physiol Res 67 (Suppl 3): S455-S464, 2018. https://doi.org/10.33549/physiolres.934005 
VOM STEEG LG, KLEIN SL: Sex steroids mediate bidirectional interactions between hosts and microbes. Horm Behav 88: 45-51, 2017. https://doi.org/10.1016/j.yhbeh.2016.10.016

WAN HT, MRUK DD, WONG CK, CHENG CY: Targeting testis-specific proteins to inhibit spermatogenesis: lesson from endocrine disrupting chemicals. Expert Opin Ther Targets 17: 839-855, 2013. https://doi.org/10.1517/14728222.2013.791679

WANG C, YUE S, HAO Z, REN G, LU D, ZHANG Q, ZHAO M: Pubertal exposure to the endocrine disruptor mono2-ethylhexyl ester at body burden level caused cholesterol imbalance in mice. Environ Pollut 244: 657-666, 2019. https://doi.org/10.1016/j.envpol.2018.08.091

WANG T, XIE C, YU P, FANG F, ZHU J, CHENG J, GU A, WANG J, XIAO H: Involvement of inzulin signaling disturbances in bisphenol a-induced Alzheimer's disease-like neurotoxicity. Sci Rep 7: 7497, 2017. https://doi.org/10.1038/s41598-017-07544-7

WARING RH, HARRIS RM: Endocrine disrupters-a threat to women's health? Maturitas 68: 111-115, 2011. https://doi.org/10.1016/j.maturitas.2010.10.008

WEISS B: Endocrine disruptors as a threat to neurological function. J Neurol Sci 305: 11-21, 2011. https://doi.org/10.1016/j.jns.2011.03.014

WU D, HUANG CJ, JIAO XF, DING ZM, ZHANG SX, MIAO YL, HUO LJ: Bisphenol AF compromises blood-testis barrier integrity and sperm quality in mice. Chemosphere 237: 124410, 2019. https://doi.org/10.1016/j.chemosphere.2019.124410

ZHANG L, NICHOLS RG, CORRELL J, MURRAY IA, TANAKA N, SMITH PB, HUBBARD TD, SEBASTIAN A, ALBERT I, HATZAKIS E, GONZALEZ FJ, PERDEW GH, PATTERSON AD: Persistent organic pollutants modify gut microbiota-host metabolic homeostasis in mice through aryl hydrocarbon receptor activation. Environ Health Perspect 123: 679-688, 2015. https://doi.org/10.1289/ehp.1409055 